\title{
CYTOTOXIC ACTIVITY OF A NEW ISOFORM L-AMINO ACID OXIDASE (BALT-LAAO-II) FROM BOTHROPS ALTERNATUS (URUTU) SNAKE VENOM IN HUMAN LEUKEMIC HL60 CELLS
}

\author{
Maurício Aurelio Gomes Heleno ${ }^{1}$, \\ João Ernesto de Carvalho ${ }^{3}$, Alexandre Nowill ${ }^{2}$ and Luis Alberto Ponce-Soto *1
}

${ }^{1}$ Departamento de Bioquímica, Instituto de Biologia, ${ }^{2} \mathrm{CIPOI}$, Faculdade de Ciências Médicas e ${ }^{3}$ Setor de Farmacologia, CPQBA, Universidade Estadual de Campinas (UNICAMP), 13083-970, Campinas, SP, Brazil

*corresponding author:

Prof. Luis Alberto Ponce-Soto Ph.D.

Departamento de Bioquímica, Instituto de Biologia Universidade Estadual de Campinas (UNICAMP) PO Box 6109 Zip code 13083-970, Campinas, SP, Brazil Fax: 55 (19) 35216129

e-mail: poncesoto@yahoo.com.ar

Key words: antitumor, apoptosis, Bothrops, cancer, cytotoxicity, L-amino acid oxidase, snake venom. 


\begin{abstract}
In this work we describe the isolation of a new isoform L-amino acid oxidase (LAAO) referred to as Balt-LAAO-II from Bothrops alternatus snake venom, which was highly purified using a combination of molecular exclusion (Sephadex G-75) and RP-HPLC chromatographics steps. When analyzed by SDS-PAGE, the purified Balt-LAAO-II presented a molecular weight of $\sim 66 \mathrm{kDa}$. The N-terminal amino acid sequence and internal peptide sequences showed close structural homology to other snake venom L-amino acid oxidases.

This enzyme induces in vitro cytotoxicity on cultured human leukemic HL60 cells. Cells were grown in RPMI medium and were incubated with isoform Balt-LAAO-II $(1,10$ and $100 \mu \mathrm{g} / \mathrm{mL}$ ) for up to $72 \mathrm{~h}$. All three concentrations of venom markedly decreased the cell viability from $6 \mathrm{~h}$ onwards based on the staining with propidium iodide, the reduction of 3(4,5-dimethylthazol-2-yl)-2,5-diphenyl tetrazolium bromide (MTT) and the uptake of neutral red.

Flow cytometry showed that all isoform Balt-LAAO-II and whole venom concentrations induced apoptosis after 2-6 h of incubation. Morphological analysis of cells incubated with isoform Balt-LAAO-II and whole venom showed cell rounding and lysis that increased with the venom concentration and duration of incubation. These results show that isoform Balt-LAAO-II from venom Bothrops alternatus is cytotoxic to cultured HL60 cells and suggest that this damage may involve apoptotic and oxidative stress pathways.
\end{abstract}




\section{Introduction}

The snake Bothrops alternatus occurs in southeastern and southern Brazil, Paraguay, Uruguay and northern Argentina (Campbell and Lamar, 1989). The venom of this species contains enzymes common to other Bothrops spp., including a thrombin-like enzyme (Smolka et al., 1998), a non-enzymatic thrombin inhibitor (Castro et al., 1998), metalloproteinases/ disintegrins (Souza et al., 2000; Cominetti et al., 2003), phosphodiesterase (Valério et al., 2002) and phospholipase $A_{2}$ (Nisenbom et al., 1986a,b, 1988). One isoform of L-amino acid oxidase, descried as Balt-LAAO-I is an acidic glycoprotein, pI 5.37, homodimeric, Mr 123, 000, whose N-terminal sequence is ADVRNPLE EFRETDYEVL ... and induces platelet aggregation and shows bactericidal activity against Escherichia coli and Staphylococcus aureus. In addition, this enzyme is slightly hemorrhagic and induces edema in the mouse paw (Rodrigo G. Stábeli et al., 2004) and PLA 2 homólogous K49 (Ponce-Soto et al., 2007, 2009). Although Bothrops alternatus venom can produce local cellular damage such as necrosis, little is known about its cytotoxic action on malignant cells.

L-Amino acid oxidases (LAAOs, EC 1.4.3.2) are flavoenzymes catalyzing the stereospecific oxidative deamination of a wide range of L-amino acids to form corresponding $\alpha$-keto acids, $\mathrm{H}_{2} \mathrm{O}_{2}$ and ammonia via an imino acid intermediate. LAAOs are widely distributed in the venomous snake families Viperidae, Crotalidae and Elapidae (Du and Clemetson, 2002; Tan and Fung, 2009). The enzyme exhibits a wide range of biological activities including apoptosis-inducing, edema-inducing, inhibition or induction of platelet aggregation, antibacterial effect and antiviral activity (Tan and Fung, 2009). They can also have antimicrobial, antiprotozoal or anticoagulant activity, be cytotoxic and antiproliferative on tumour cells (Santos et al., 2004, Izidoro, et al., 2006). The role of LAAO in the pharmacological action of snake venom, however, is still not fully understood. Generally, the enzyme has a low lethal toxicity in mice.

Apoptotic processes and cellular damage are mechanisms of action of some toxins, and several studies show potential applications of such substances as models for the development of chemotherapy and anticancer agents. In view of the lack of information, we have purified an isoform of L-amino acid oxidase (LAAO) from Bothrops alternatus venom named Balt-LAAO-II and have studied some of its biochemical and cytotoxicity activity on cancer cells of the human leukemic cell line HL60. Our results have important implications for understanding the envenomation by Bothrops alternatus as well as the mechanisms of cell death triggered by this group of enzymes and provide a foundation for further investigations. 


\section{Material and Methods}

\section{$2.1 \quad$ Venom and reagents}

Bothrops alternatus venom was a gift from the Batatais Serpentarium, Batatais, SP, Brazil. All chemicals and reagents used in this work were of analytical or sequencing grade. Fetal calf serum (FCS), 3-(4,5-dimethylthazol-2-yl)-2,5-diphenyl tetrazolium bromide (MTT), glutamine, sodium pyruvate, penicillin and streptomycin were obtained from Sigma Chemical Co. (St. Louis, MO, USA), aracityn was from Pfizer, and RPMI medium was from Gibco Life Technologies (Paisley, Scotland). Annexin V/propidium iodide apoptosis detection kits were obtained from R\&D Systems Inc. (Minneapolis, MN, USA). Sterile multiwell culture plates were from Corning Inc. (Corning, NY, USA). The other reagents of analytical grade were from Baker, Mallinkrodt or Merck.

\subsection{Isolation of of L-amino acid oxidase from Bothrops alternatus venom.}

Molecular exclusion chromatography: Approximately $35 \mathrm{mg}$ of the whole venom of Bothrops alternatus was dissolved in $400 \mu \mathrm{l}$ ammonium bicarbonate buffer $(0,2 \mathrm{M} ; \mathrm{pH} 8.0)$ and homogenized up to complete dissolution, followed by clarification with high speed centrifugation (4500x $g$ for 2min). The supernatant was fractionated on a Sephadex G75 (Pharmacia) column $(1.6 \times 100 \mathrm{~cm})$ pre-equilibrated with ammonium bicarbonate buffer. The flow rate was $0.2 \mathrm{ml} / \mathrm{min}$ and the elution profile was monitored at $280 \mathrm{~nm}$. The fractions collected were immediately lyophilized and stored at $-40^{\circ} \mathrm{C}$.

The samples were applied at a flow rate of $1 \mathrm{~mL} / \mathrm{min}$ onto reversed-phase liquid chromatography (RP-HPLC) C18 column $(20$ x $250 \mathrm{~mm})$. Fractions containing LAAO were pooled and stored at $-20^{\circ} \mathrm{C}$.

The molecular homogeneity of this protein was evaluated by reverse-phase HPLC ( 0.1 x $30 \mathrm{~cm}$ column of $\mu$-Bondapack C-4, Waters) using a linear and discontinuous gradient 0 $100 \%$ of acetonitrile in $0.1 \%$ trifluoroacetic acid (TFA) (v/v). Afterwards, $3 \mathrm{mg}$ of the LAO protein from the RP-HPLC was dissolved in $250 \mathrm{~mL}$ of buffer A $(0.1 \%$ TFA) and centrifuged at $4500 \mathrm{~g}$ for $2 \mathrm{~min}$ and the supernatant was then applied on the analytical reverse-phase HPLC, previously equilibrated with buffer A for $15 \mathrm{~min}$. The elution of the protein was then conducted using a linear gradient of buffer B (66.6\% acetonitrile in buffer A) monitored at $280 \mathrm{~nm}$. After elution, the fraction was lyophilized and stored at $-40^{\circ} \mathrm{C}$. The purity of the LAO was also assayed using PAGE-SDS electrophoresis.

\subsection{Protein determination and L-amino acid oxidase assay}


Total protein was evaluated by the microbiuret assay (Johnson, 1978). L-amino acid oxidase $(15 \mu \mathrm{g})$ activity was determined by a spectrophotometric assay using L-leucine as substrate (Pessatti et al., 1995). In this assay, the oxidative deamination of L-leucine produced hydrogen peroxide, which was reduced in the presence of horseradish peroxidase (BiolabsINC, New England) by $o$-phenylenediamine to produce a colored oxidized product, which was spectrophotometrically monitored at $490 \mathrm{~nm}$. The assay mixture with $10 \mathrm{~mL}$ of L-leucine $1 \%$ in Tris- $\mathrm{HCl} 0.1 \mathrm{M}(\mathrm{pH} 7.2)$ contained $16 \mu \mathrm{L}$ horseradish peroxidase $(1 \mathrm{mg} / \mathrm{mL})$ and 100 $\mu \mathrm{L} o$-phenylenediamine $(10 \mathrm{mg} / \mathrm{mL}$ in methanol). After $30 \mathrm{~min}$, the reaction was stopped by addition of $10 \%(\mathrm{w} / \mathrm{v})$ citric acid. For enzymatic specificity assays, L-leucine was replaced by other L-amino acids (2 mmol), namely: Leu, Ile, Met, Cys, Val, Tyr, Trp, Gln, Thr, Ser, Lys, Arg, Phe, Asn, Glu, Gly, Pro, Asp and His, at the same concentration and assayed for activity under identical conditions.

\section{$2.4 \quad$ Cell culture}

HL60 cells were grown in RPMI medium supplemented with 10\% FCS and 2 mM Lglutamine, $1 \mathrm{mM}$ sodium pyruvate, $100 \mu \mathrm{g}$ of penicillin $/ \mathrm{mL}$ and $100 \mu \mathrm{g}$ of streptomycin $/ \mathrm{mL}$ in a humidified atmosphere with $5 \% \mathrm{CO}_{2}$ at $37^{\circ} \mathrm{C}$. The cytotoxicity of the venom was tested by incubating the cells with medium containing Bothrops alternatus venom (1, 10 and $100 \mu \mathrm{g} / \mathrm{mL})$ or fractions $(10 \mu \mathrm{g} / \mathrm{mL})$ for $2,6,24,48$ and $72 \mathrm{~h}$.

\subsection{Cytotoxicity assays}

\subsubsection{Neutral red uptake}

Cells grown in 96-well plates were treated with LAAO venom as described above. After incubation with venom the cells were centrifuged and the was medium removed from the plates prior to the addition of $200 \mu \mathrm{l}$ of neutral red solution (Seromed; final concentration of $50 \mu \mathrm{g} / \mathrm{mL}$ ) were added to each well. The plates were then incubated for $3 \mathrm{~h}$ at $37^{\circ} \mathrm{C}$, after which the cells were centrifuged and the medium was removed. The cells were then rapidly washed with $200 \mu \mathrm{L}$ of fixative ( $1 \% \mathrm{v} / \mathrm{v}$ formaldehyde, $\left.1 \% \mathrm{w} / \mathrm{v} \mathrm{CaCl}_{2}\right)$, centrifuged and the fixative removed. One hundred microliters of a solution of $1 \%$ acetic acid and $50 \%$ ethanol was then added to the wells to extract the dye. After incubation for $1 \mathrm{~h}$ on a microtiter plate shaker at room temperature, the plates were read at $540 \mathrm{~nm}$ on a microplate reader (SpectraMax 340, Molecular Devices, Sunnyvale, CA, USA). 


\subsubsection{MTT reduction}

Cells grown in 96-well plates were treated with LAAO as described above. At the end of the incubations, the cells were centrifuged, the supernatant was removed and $10 \mu \mathrm{L}$ of a solution of MTT (3-(4,5-dimethylthazol-2-yl)-2,5-diphenyl tetrazolium bromide) $(5 \mathrm{mg} / \mathrm{mL})$ and $100 \mu \mathrm{l}$ of PBS were added to each well. After incubation for $3 \mathrm{~h}$ at $37^{\circ} \mathrm{C}, 100 \mu \mathrm{L}$ of isopropanol were added to the wells and the plates then incubated with shaking for $10 \mathrm{~min}$ prior to reading the absorbance at $570 \mathrm{~nm}$ in a SpectraMax microplate reader

\subsubsection{Cell viability and flow cytometry}

Cell viability was assessed by staining with propidium iodide, essentially as described below for flow cytometry. HL60 cells control, annexin, whole venom from Bothrops alternatus and Balt-LAAO-II $(10 \mu \mathrm{g} / \mathrm{mL})$. Cells grown in six-well plates were treated annexin, whole venom from Bothrops alternatus and Balt-LAAO-II as described above and processed for the detection of apoptosis by flow cytometry using a commercial kit. At the end of each incubation with venom, the cells were pelleted by centrifugation $(200 \mathrm{x} g, 10 \mathrm{~min}$, $\sim 25^{\circ} \mathrm{C}$ ), the supernatant was removed and $2 \mathrm{ml}$ of PBS was added. After a further centrifugation, the supernatant was discarded and $400 \mu \mathrm{l}$ of cold binding buffer $(0.1 \mathrm{M}$ Hepes/NaOH, pH 7.4, $1.4 \mathrm{M} \mathrm{NaCl}, 25 \mathrm{mM} \mathrm{CaCl}_{2}$ ) were added to each tube followed by vortex mixing and incubation for $15 \mathrm{~min}$ on ice. After this period, $10 \mu \mathrm{l}$ of concentrated calcium solution was added, and the tubes vortexed prior to the addition of $1 \mu \mathrm{L}$ of annexin $\mathrm{V}$ to each tube. The tubes were vortexed again and $10 \mu \mathrm{L}$ of propidium iodide were added to the tubes. The cells were analyzed by flow cytometry (BD Technologies) immediately or stored on ice in the dark until analysis (within $30 \mathrm{~min}$ ).

\subsection{Morphological observations}

The changes in cell appearance following incubation with whole venom from Bothrops alternatus and Balt-LAAO-II, were monitored with a Zeiss inverted light microscope fitted with a digital camera. The venom-induced alterations were compared with corresponding control cells. 


\section{$2.7 \quad$ Statistical analysis}

The results were expressed as the mean+S.E.M., as appropriate. Statistical comparisons between groups were done using analysis of variance (ANOVA) followed by the Bonferroni test. Values of $p<0.05$ were considered significant.

\section{Results}

\subsection{Biochemical and structural analysis of L-amino acid oxidase (Balt-LAAO-II) from}

Bothrops alternatus (urutu) snake venom.

The fractionation of Bothrops alternatus snake venom on Sephadex G-75 column allowed the purification of three major fractions, named fractions I, II, III, IV and V (Fig. 1). Enzymatic assay of fraction I confirmed the characteristic action described for L-amino acid oxidase (LAAO).

Re-chromatography of L-amino acid oxidase (fraction I) by ion exchange HPLC Protein Pack DEAE 5PW column, produced nine peaks, the main ones being I-1 - I-9 (Fig. 2). All fractions obtained by this procedure were eluted with less than $0.5 \mathrm{M}$ buffer and were easily lyophilized with no need for dialysis. The peaks I-3 and I-4 showed isoforms of Lamino acid oxidase.

The re-chromatography of peak I-4 by RP-HPLC resulted in one peaks, with retention times corresponding to $30.2 \pm 0.02 \mathrm{~min}$ (I-4) of time retention. (Fig. 2 insert). The N-terminal sequences of isoform I-4 (Balt-LAAO-II) showed high amino acid sequence identity with other LAOs (Fig. 3).

The first 40 amino acid residues of Balt-LAAO-II were identified by automated Edman degradation and provide additional evidence for the purity of the enzyme and homology between different venom L-amino acid oxidases (Fig. 3). Comparison of the Nterminal sequence of Balt-LAAO-II with that of enzymes isolated from other snake venoms revealed high homology with LAAOs from viperid venoms. In the N-terminal sequence, at least 20 of the 40 amino acid residues were found to be fully conserved in all sequences, thus suggesting the presence of a highly conserved Glu-rich motif.

The affinity of Balt-LAAO-II to different substrates was accessed for further biochemical characterization. The enzyme showed higher affinity to the hydrophobic amino acids L-Met, L-Leu, L-Phe and L-Ile. For other amino acids, the catalytic affinity was very low (Ala, Val, Glu and Tyr) or inexistent (L-Pro, L-Thr, L-Ser and L-Cys) (Data not show). 


\subsection{Cytotoxicity assays}

Figure 4, shows the cell viability assessed by staining with MMT reduction (A) after incubation with isoform L-amino acid oxidase Balt-LAAO-II for various periods of time. All L-amino acid oxidase Balt-LAAO-II concentrations caused a decrease in cell viability after 6 $\mathrm{h}$ that was very marked after $24 \mathrm{~h}$. The decrease in Neutral red (B) and Blue trypan uptake (C) caused by L-amino acid oxidase Balt-LAAO-II paralleled the changes in viability.

\subsection{Venom-induced apoptosis}

Flow cytometry of HL60 showed that whole venom and L-amino acid oxidase BaltLAAO-II $(10 \mu \mathrm{g} / \mathrm{mL})$ from Bothrops alternatus, caused apoptosis from $6 \mathrm{~h}$ onwards that was maximal after $24 \mathrm{~h}$ (Figure 5C and D. Figure 5A and B control negative and positive). Number of cells showing apoptosis after incubation with different concentrations of fractions obtained by gel filtration Sephadex G-75 from Bothrops alternatus snake venom $(10 \mu \mathrm{g} / \mathrm{mL})$ and (B) differents concentrations of Balt-LAAO-II. Aracityn (20 $\mathrm{nM})$ was used as a positive control (Figure 6).

\subsection{Cell morphology}

Figure 7 shows that the incubation of HL60 cells with venom Bothrops alternatus and L-amino acid oxidase Balt-LAAO-II, produced marked time-dependent changes in cell morphology, with the main alterations being rounding of the cells and subsequent lysis.

\section{Discussion}

L-Amino acid oxidases are widely expressed in snake venoms and catalyze the oxidative deamination of L-amino acids, producing the corresponding $\alpha$-ketoacids, hydrogen peroxide and ammonia. They are usually homodimeric, FAD-binding glycoproteins, with molecular mass around 110-150 kDa when measured by gel filtration under non-denaturing conditions. However, the molecular mass of L-Amino acid oxidases from snake is around 50$70 \mathrm{kDa}$ when assayed by SDSPAGE, both under reducing and non-reducing conditions. Thus, most of the L-Amino acid oxidases from snake are homodimeric glycoproteins associated by non-covalent bonds with pI of approximately 4.4-8.2 (D. Butzke et al., 2005, G. Ponnudurai et al., 1994, Y. Jin et al., 2007, Raquel de Melo Alves Paiva et al., 2011. Gustavo B. Naumann et al., 2011).

In the present work, we isolated a new isoform of L-Amino acid oxidases from Bothrops alternatus snake venom (Balt-LAAO-II) by using two chromatographic steps 
(molecular exclusion in Sephadex G75 and ion exchange Protein Pack DEAE 5PW column HPLC) and finally the active fraction was still analyzed for purity by reverse phase HPLC chromatography. Balt-LAAO-II presented molecular weight of approximately $\sim 66 \mathrm{kDa}$ in SDS-PAGE.

The enzyme showed high affinity for L-Leu is the most favorable substrate for evaluating the enzymatic activity of purified snake venom L-Amino acid oxidases, but high catalytic activity was detected against L-Met for Balt-LAAO-II. At the same way, L-Amino acid oxidases from Bothrops alternatus, Bothrops pirajai and Bothrops moojeni favor the specific substrates of hydrophobic amino acids (L-PheNL-MetNL-LeuNL-Ile) (França et al., 2007; Stábeli et al., 2004). The catalytic differences may be explained by differences in side chain binding sites responsible for the substrate specificity of the enzyme (Samel et al., 2006).

The N-terminal sequence of amino acids shows a high homology to other members of this family of toxins, including the presence of a highly conserved Glu rich motif, which may play a role in substrate binding. In agreement with the structure of L-Amino acid oxidases from Calloselasma rhodostoma (P. Macheroux et al., 2001), this N-terminal region (5-25 residues) constitutes one part of the substrate-binding domain. Our finding of 2-DE that the enzyme has a range of isoelectric points (pI) from about 5.8 to 6.1, reflects the presence of isoforms with distinct pIs similarly to other snake venom L-Amino acid oxidases (Y.H. Sakurai et al., 2001, S.A. Ali et al., 2000, P.D. Pawelek et al., 2000). However, the existence and the nature of the possible isoforms have to be further investigated.

The presence of isoforms may be due to different composition or different glycosylation as revealed for other homologous flavoenzymes (Sakurai et al., 2001, R.G. Stabeli et al., 2004), or they may have been synthesized from different genes as was suggested for two distinct L-Amino acid oxidases from Pseudechis australis (B.G. Stiles et al., 1991). Moreover, heterogeneous glycosylation of isoform Balt-LAAO-II may also cause this divergence and would not be surprising as the venom used for purification of Balt-LAAO-II was collected from only two snake individuals.

Venomous animals have evolved a vast array of toxins for prey capture and defense. Toxins as L-amino acid oxidases have been reported to show potent applications in pharmacology and cancer therapy (X.Y. Du, K.J. Clemetson 2002). As the balance between therapeutic potential and toxic side effects of a toxin is very important when evaluating its usefulness as a pharmacological drug, experiments were designed to investigate the in vitro cytotoxicity of Balt-LAAO-II against human cancer cells (HL-60). 
Apoxin-I, a Crotalus atrox L-amino acid oxidases, induced apoptosis mediated by $\mathrm{H}_{2} \mathrm{O}_{2}$ S. (Torii et al., 2000). However, Suhr et al., (1996) demonstrated that the L-amino acid oxidases induced apoptotic mechanism is clearly distinguishable from the one stimulated directly by exogenous $\mathrm{H}_{2} \mathrm{O}_{2}$, suggesting that the L-amino acid oxidases induced apoptosis was not solely due to the $\mathrm{H}_{2} \mathrm{O}_{2}$ produced by the enzymatic reaction. However, the molecular details as to which intracellular components are specifically associated with L-amino acid oxidases induced apoptosis are still unknown. In addition, Balt-LAAO-II induced mouse paw edema (data not shown). However, the enzyme is neither hemorrhagic nor myotoxic at doses of up to $100 \mu \mathrm{g} / \mathrm{animal}$ (data not shown). The physiological role of L-amino acid oxidases in snake envenomation is not well understood. Venom L-amino acid oxidases share many biological effects, and this study and others demonstrated that these effects were mainly due to the production of $\mathrm{H}_{2} \mathrm{O}_{2}$ by the enzymatic reaction. The exact molecular mechanisms of these effects are still being investigated. Balt-LAAO-II induced dose-dependent cytotoxicity in human leukemic HL60 cells.

The close correlation between cell viability and the decrease in the uptake of neutral red, blue trypan and in MTT reduction, which assess lysosomal and mitochondrial function, respectively, suggested that the cytotoxic action of the venom involved primarily cell lysis rather than the disturbance of energy production and metabolism (Figure 4A, B and C). Other studies have also reported an antiproliferative action for Bothrops venoms and their components both in vitro and in vivo (Pereira-Bittencourt et al., 1999; de Carvalho et al., 2001; Corrêa et al., 2002; da Silva et al., 2002a, b).

Balt-LAAO-II and whole venom from Bothrops alternatus snake venom, induced cell death in HL-60 cell line. In this study, flow cytometry (Figure 5) was utilized to confirm the results obtained from morphological assessment of cell death by microscopy (Figure 6) The morphological alterations seen in HL60 cells following incubation with venom (rounding and lysis) were similar to those reported for other Bothrops venoms (Collares-Buzato et al., 2002) and their isolated components (Borkow et al., 1995; Corrêa et al., 2002). In adherent cells, loss of contact with the substrate partly reflects the action of venom disintegrins which bind to cell adhesion molecules (integrins) present on the cell surface (Kamiguti et al., 1998). The integrins known to be affected by Bothrops venom disintegrins include $\alpha 1 \beta 3$ (Rucinski et al., 1990), $\alpha 2 \beta 1$ (Souza et al., 2000; Moura-da-Silva et al., 2001) and $\alpha 5 \beta 1$ (Cominetti et al., 2003). In contrast, $\alpha \mathrm{II} \beta 3, \alpha 1 \beta 1, \alpha 5 \beta 1, \alpha 4 \beta 1, \alpha v \beta 3$ and a9b1 are not targets for the disintegrin alternagin-C from Bothrops alternatus venom (Souza et al., 2000). Cominetti et al. 
(2003) have recently shown that $\mathrm{BaG}$, another metalloproteinase/disintegin from Bothrops alternatus venom, binds to $\alpha 5 \beta 1$ in K562 cells grown in suspension (as are HL60 cells). We found that the apoptotic index increased in the HL-60 cell line in a dose-dependent manner after treatmen twith whole venom and Balt-LAAO-II (Figure 7). Most of the biological effects of L-amino acid oxidases are believed to be due the secondary effect of $\mathrm{H}_{2} \mathrm{O}_{2}$ produced by enzymatic reactions (Massey and Curti, 1967; Tan and Ponnudurai, 1992). As H2O2 is permeable, it crosses the cellular plasmatic membrane, linking to DNA and causing cellular apoptosis. The authors suggests that this mechanism could be related to significant inhibition of in vitro cell growth HL-60 by action of L-amino acid oxidases Bal-LAAO-II . Furthermore, L-amino acid nutrients that are substrates of L-amino acid oxidases reactions are consumed in a way that can avoid proliferation of tumour cells (Kanzawa N et al., 2004) because they need the correct environment in which to develop and proliferate.

These results demonstrate that Bothrops alternatus venom contains an important substance the future anticancer drug development from snake venom and its mechanism of action. Lamino acid oxidases could effectively trigger cell apoptosis in vitro. Further studies will be necessary to be carried out to discover the structure and the sites of activity of BaltLAAO-II.

\section{Acknowledgments}

The authors thank José Ilton dos Santos and Gilberto Franchi Jr. for technical assistance. 


\section{References}

Borkow G, Gutiérrez JM, Ovadia M (1995) In vitro activity of BaH1, the main hemorrhagic toxin of Bothrops asper snake venom on bovine endothelial cells. Toxicon 33, 13871391.

Butron E, Ghelestam M, Gutiérrez JM (1993) Effects on cultured mammalian cells of myotoxin III, a phospholipase $\mathrm{A}_{2}$ isolated from Bothrops asper (terciopelo) venom. Biochim. Biophys. Acta 1179, 253-259.

Campbell JA, Lamar W (1989) Venomous Reptiles of Latin America. Comstock Publishers/Cornell University Press, Ithaca, NY.

Castro HC, Dutra DL, Oliveira-Carvalho AL, Zingali RB (1998) Bothroalternin, a thrombin inhibitor from the venom of Bothrops alternatus. Toxicon 36, 1903-1912.

Coelho AL, de Freitas MS, Oliveira-Carvalho AL, Moura-Neto V, Zingali RB, Barja-Fidalgo $C$ (1999) Effects of jarastatin, a novel snake venom disintegrin, on neutrophil migration and actin cytoskeleton dynamics. Exp. Cell Res. 251, 379-387.

Collares-Buzato CB, de Paula Le Sueur L, da Cruz-Höfling MA (2002) Impairment of the cell-to-matrix adhesion and cytotoxicity induced by Bothrops moojeni snake venom in cultured renal tubular epithelia. Toxicol. Appl. Pharmacol. 181, 124-132.

Corrêa MC Jr, Maria DA, Moura-da Silva AM, Pizzocaro KF, Ruiz IR (2002) Inhibition of melanoma cells tumorigenicity by the snake venom toxin jararahagin. Toxicon 40, 739748.

Cotte CA, Essenfeld-Yahr E, Lairet AC (1972) Effects of Crotalus and Bothrops venom on normal and malignant cells cultivated in vitro. Toxicon 10, 157-161.

Costa TR, Burin SM, Menaldo DL, Castro FA, Sampaio SV (2014) Snake venom L-amino acid oxidases: an overview on their antitumor effects. Journal of Venomous Animals and Toxins including Tropical Diseases 20:23

da Silva RJ, da Silva MG, Vilela LC, Fecchio D (2002a) Antitumor effect of Bothrops jararaca venom. Mediators Inflamm. 11, 99-104.

da Silva RJ, da Silva MG, Vilela LC, Fecchio D (2002b) Cytokine profile of Ehrlich ascites tumor treated with Bothrops jararaca venom. Mediators Inflamm. 11, 197-201.

Daniele JJ, Bianco ID, Delgado C, Carrillo DB, Fidelio GB (1997) A new phospholipase $A_{2}$ isoform isolated from Bothrops neuwiedii (yarara chica) venom with novel kinetic and chromatographic properties. Toxicon 35, 1205-1215.

de Carvalho DD, Schmitmeier S, Novello JC, Markland FS (2001) Effect of BjcuL (a lectin from the venom of the snake Bothrops jararacussu) on adhesion and growth of tumor and endothelial cells. Toxicon 39, 1471-1476.

Du XY, Clemetson KJ (2002) Snake venom L-amino acid oxidases. Toxicon 40, 659-656.

Fletcher JE, Jiang MS (1998) LYS49 phospholipase $A_{2}$ myotoxins lyse cell cultures by two distinct mechanisms Toxicon 36, 1549-1555.

Gallagher PG, Bao Y, Serrano SM, Kamiguti S, Theakston RD, Fox JW (2003) Use of microarrays for investigating the subtoxic effects of snake venoms: insights into venominduced apoptosis in human umbilical vein endothelial cells. Toxicon 41, 429-440.

Goni A, Vaisberg A, Zavaleta A (1992) Cytotoxicity induced by Peruvian snake venom on fibroblasts of mice. Rev. Biol. Trop. 40, 143-145.

Gutiérrez JM, Lomonte B (1995) Phospholipase $A_{2}$ myotoxins from Bothrops snake venoms. Toxicon 33, 1405-1424.

Gutiérrez JM, Rucavado A (2000) Snake venom metalloproteinases: their role in the pathogenesis of local tissue damage. Biochimie 82, 841-850. 
Guzzie PJ (1994) Lethality testing. In: In Vitro Toxicology. Shayne CG (ed). pp. 57-86. Raven Press: New York.

Hamilton TC, Young RC, McKoy WM, Grotzinger KR, Green JA, Chu EW, Whang-Peng J, Rogan AM, Green WR, Ozols RF (1983) Characterization of a human ovarian carcinoma cell line (NIH:OVCAR-3) with androgen and estrogen receptors. Cancer Res. 43, 5379-5389.

Herkert M, Shakhman O, Shweins E, Becker CM (2001) Beta-bungarotoxin is a potent inducer of apoptosis in cultured rat neurons by receptor-mediated internalization. Eur. $J$. Neurosci. 14, 821-828.

Kamiguti AS, Zuzel M, Theakston RD (1998) Snake venom metalloproteinases and disintegrins: interactions with cells. Braz. J. Med. Biol. Res. 31, 853-862

Lomonte B, Angulo Y, Rufini S, Cho W, Giglio JR, Ohno M, Daniele JJ, Geoghegan P, Gutiérrez JM (1999) Comparative study of the cytolytic activity of myotoxic phospholipases $\mathrm{A}_{2}$ on mouse endothelial (tEnd) and skeletal muscle $(\mathrm{C} 2 \mathrm{C} 12)$ cells in vitro. Toxicon 37, 145-158.

Lomonte B, Tarkowski A, Hanson LA (1994) Broad cytolytic specificity of myotoxin II, a lysine-49 phospholipase $A_{2}$ of Bothrops asper snake venom. Toxicon 32, 1359-1369.

Masuda S, Hayashi H, Araki S (1998) Two vascular apotosis-inducing proteins from snake venom are members of the metalloprotease/disintegrin family. Eur. J. Biochem. 253, 3641.

Masuda S, Hayashi H, Atoda H, Morita T, Araki S (2001) Purification, cDNA cloning and characterization of the vascular apoptosis-inducing protein, HVI, from Trimeresurus flavoviridis. Eur. J. Biochem. 268, 3339-3345.

Masuda S, Ohta T, Kaji K, Fox JW, Hayashi H, Araki S (2000) cDNA cloning and characterization of vascular apoptosis-inducing protein 1. Biochem. Biophys. Res. Commun. 278, 197-204.

Morte RD, Squillacioti C, Barbi C, Derkinderen P, Belisario MA, Girault JA, Di Natale P, Nitsch L, Staiano N (2000) Echistatin inhibits pp125 $5^{\text {FAK }}$ autophosphorylation, paxillin phoshorylation and pp125 $5^{\mathrm{FAK}}$-paxillin interaction in fibronectin-adherent melanoma cells. Eur. J. Biochem. 267, 5047-5054.

Moura-da-Silva AM, Laing GD, Paine MJ, Dennison JM, Politi V, Crampton JM, Theakston RD (1996) Processing of pro-tumor necrosis factor-alpha by venom metalloproteinases: a hypothesis explaining local tissue damage following snake bite. Eur. J. Immunol. 26, 2000-2005.

Moura-da-Silva AM, Marcinkiewicz C, Marcinkiewicz M, Niewiarowski S (2001) Selective recognition of the alpha2beta1 integrin by jararhagin, a metalloproteinase/disintegrin from Bothrops jararaca venom. Thromb. Res. 102, 153-159.

Nascimento JM, Franchi GC, Nowill AE, Collares-Buzato CB, Hyslop S (2007). Cytoskeletal rearrangement and cell death induced by Bothrops alternatus snake venom in cultured Madin-Darby canine kidney cells. Biochem Cell Biol 85(5), 591-605.

Nisenbom HE, Perazzo JC, Monserrat AJ, Vidal JC (1986b) Contribution of phospholipase $\mathrm{A}_{2}$ to the lethal potency of Bothrops alternatus (vibora de la cruz) venom. Toxicon 24, 807-817.

Nisenbom HE, Perazzo JC, Monserrat AJ, Vidal JC (1988) Effect of chemical modification with p-bromophenacyl bromide on the enzymatic and lethal properties of phospholipase $\mathrm{A}_{2}$ from Bothrops alternatus (vibora de la cruz) venom. Toxicon 26, 1137-1144.

Nisenbom HE, Seki C, Vidal JC (1986a) Phospholipase $A_{2}$ from Bothrops alternatus (vibora de la cruz) venom. Purification and some characteristic properties. Toxicon 24, 259-272.

Nunez CE, Angulo Y, Lomonte B (2001) Identification of the myotoxic site of the Lys49 phospholipase $\mathrm{A}_{2}$ from Agkistrodon piscivorus piscivorus snake venom: synthetic C- 
terminal peptides from Lys49, but not from Asp49 myotoxins, exert membranedamaging activities. Toxicon 39, 1587-1594.

Oliveira JC, de Oca HM, Duarte MM, Diniz CR, Fortes-Dias CL (2002) Toxicity of South American snake venoms measured by an in vitro cell culture assay. Toxicon 40, 321325.

Pereira-Bittencourt M, Carvalho DD, Gagliardi AR, Collins DC (1999) The effect of a lectin from the venom of the snake, Bothrops jararacussu, on tumor cell proliferation. Anticancer Res. 19, 4023-4025.

Renzi D, Valtolina M, Forster R (1993) The evaluation of a multi-endpoint cytotoxicity assay system. ATLA 21, 89-96.

Ritter MR, Markland FS Jr (2001) Differential regulation of tyrosine phosphorylation in tumor cells by contortrostatin, a homodimeric disintegrin, and monomeric disintegrins echistatin and flavoviridin. Toxicon 39, 283-289.

Ritter MR, Zhou Q, Markland FS Jr (2000) Contortrostatin, a snake venom disintegrin, induced alphavbeta3-mediated tyrosine phosphorylation of CAS and FAK in tumor cells. J. Cell Biochem. 79, 28-37.

Ritter MR, Zhou Q, Markland FS Jr (2001) Contortrostatin, a homodimeric disintegrin, actively disrupts focal adhesion and cytoskeletal stucture and inhibits cell motility through a novel mechanism. Cell Commun. Adhes. 8, 71-86.

Rucinski B, Niewiarowski S, Holt JC, Soszka T, Knudsen KA (1990) Batroxostatin, an ArgGly-Asp-containing peptide from Bothrops atrox, is a potent inhibitor of platelet aggregation and cell interaction with fibronectin. Biochim. Biophys. Acta 1054, 257-262.

Souza DH, Iemma MR, Ferreira LL, Faria JP, Oliva ML, Zingali RB, Niewiarowski S, Selistre-de-Araújo HS (2000) The disintegrin-like domain of the snake venom metalloprotease alternagin inhibits alpha2betal integrin-mediated cell adhesion. Arch. Biochem. Biophys. 384, 341-350.

Staiano N, Garbi C, Squillacioti C, Esposito S, Di Martino E, Belisario MA, Mitsch L, Di Natale P (1997) Echistatin induces decrease of pp125 ${ }^{\text {FAK }}$ phosphorylation, disassembly of actin cytoskeleton and focal adhesions, and detachment of fibronectin-adherent melanoma cells. Eur. J. Cell Biol. 73, 298-305.

Suhr S.M., Kim D.S. (1996) Identification of the snake venom substance that induces apoptosis. Biochem. Biophys. Res. Commun. 224, 134-139.

Sun LK, Yoshii Y, Hyodo A, Tsurushima H, Saito A, Harakuni T, Li YP, Kariya K, Nozaki M, Morine N (2003) Apoptotic effect in the glioma cells induced by specific protein extracted from Okinawa habu (Trimeresurus flavoviridis) venom in relation to oxidative stress. Toxicol. In Vitro 17, 169-177.

Twentyman PR, Walls GA, Wright KA (1984) The response of tumor cells to radiation and cytotoxic drugs - a comparison of clonogenic and isotope uptake assays. Br. J. Cancer 50, 625-631.

Valério AA, Corradini AC, Panunto PC, Mello SM, Hyslop S (2002) Purification and characterization of a phosphodiesterase from Bothrops alternatus snake venom. $J$. Protein Chem. 21, 495-503.

Wu WB, Chang SC, Liau MY, Huang TF (2001) Purification, molecular cloning and mechanism of action of graminelysin I, a snake-venom-derived metalloproteinase, that induces apoptosis of human endothelial cells. Biochem. J. 357, 719-728.

Wu WB, Huang TF (2003) Activation of MMP-2, cleavage of matrix proteins, and adherens junctions during a snake venom metalloproteinase-induced endothelial cell apoptosis. Exp. Cell Res. 288, 143-157. 
Wu WB, Peng HC, Huang TF (2003) Disintegrin causes proteolysis of beta-catenin and apoptosis of endothelial cells. Involvement of cell-cell and cell-ECM interactions in regulating cell viability. Exp. Cell Res. 286, 115-127.

Yeh CH, Peng HC, Huang TF (1998) Accutin, a new disintegrin, inhibits angiogenesis in vitro and in vivo by acting as integrin alphavbeta3 antagonist and inducing apoptosis. Blood 92, 3268-3276. 


\section{Captions figures}

Figure. 1. Molecular exclusion chromatography of Bothrops alternatus snake venom on a Sephadex G-75 column $(1.6 \mathrm{~cm} \times 100 \mathrm{~cm})$ at $14^{\circ} \mathrm{C} .35 \mathrm{mg}$ of crude venom were applied to the column, equilibrated with ammonium bicarbonate buffer $0,2 \mathrm{M} ; \mathrm{pH} 8.0$ at a flow rate of 0.3 $\mathrm{ml} / \mathrm{min}$. The elution profile was monitored at $280 \mathrm{~nm}$. The main fractions obtained identified as I-V (L-amino acid oxidase peak I.) were pooled, lyophilized, and stored at $-20^{\circ} \mathrm{C}$. Insert: SDS-PAGE main fractions obtained by molecular exclusion chromatography.

Figure. 2. Chromatography on RP-HPLC of the peak I from molecular exclusion chromatography of lyophilized from Bothrops alternatus snake venom. The main fractions obtained identified as I-1 - I-9 (L-amino acid oxidase peak I-4, Balt-LAAO-II.) was pooled, lyophilized, and stored at $-20^{\circ} \mathrm{C}$. Insert: Re-chromatography and SDS-PAGE of main fraction (Balt-LAAO-II) obtained by RP-HPLC.

Figure. 3. N-terminal amino acid sequence of L-amino acid oxidase from the Bothrops alternatus venom (Balt-LAAO-II) compared with others LAAO, obtained from the BLAST similarity search (PubMed, MEDLINE): Bmoj_LAAO (Bothrops moojeni, Q6TGQ8), Bonew_LAAO (Bothrops neuwiedi), Croad_LAAO (Crotalus adamanteus, 093364), Bins_LAAO (Bothrops insularis, Braga et al., 2008), Trist_LAAO (Trimeresurus stejnegeri, Q6WP39), Agkph_LAAO (Agkistrodon piscivorus; Q6STF1) and Botpi_LAAO (Bothrops pirajai, Izidoro et al., 2006)

Figure 4. (A) Cell viability MTT reduction, (B) Neutral red and (C) Blue trypan uptake by HL60 cells incubated with different concentrations of Balt-LAAO-II isolated from Bothrops alternatus snake venom for the indicated times. The columns are the mean +1 S.E.M. of 5 experiments. ${ }^{*} p<0.05$ compared to the corresponding control.

Figure 5. Flow cytometer scattergrams showing apoptosis in HL60 cells control (A), treated with aracityn (B) $(10 \mu \mathrm{g} / \mathrm{mL})$, wolhe venom $(10 \mu \mathrm{g} / \mathrm{mL})(\mathrm{C})$ and Balt-LAAO-II $(10 \mu \mathrm{g} / \mathrm{mL})$ (D) for $6,24,48$ and $72 \mathrm{~h}$, respectively.

Figure 6. (A) Number of cells showing apoptosis after incubation with different concentrations of fractions obtained by gel filtration Sephadex G-75 from Bothrops alternatus snake venom $(10 \mu \mathrm{g} / \mathrm{mL})$ and (B) differents concentrations of Balt-LAAO-II. Aracityn (20 $\mathrm{nM}$ ) was used as a positive control.

Figure 7. Morphological alterations in HL60 cells treated with Bothrops alternatus venom $(100 \mu \mathrm{g} / \mathrm{ml})$ and L-amino acid oxidase Balt-LAAO-II $(10 \mu \mathrm{g} / \mathrm{mL})$ for 2, 6, 24, 48 and $72 \mathrm{~h}$ (A, $\mathrm{B}, \mathrm{C}, \mathrm{D}$ and E, respectively. Aracityn $(20 \mathrm{nM})$ was used as a positive control.

Table 1. Protein content and enzymatic activities of fractions obtained by molecular exclusion of Bothrops alternatus snake venom and Balt-LAAO-II. Bold values indicates highest activities fractions. 
Fig. 1

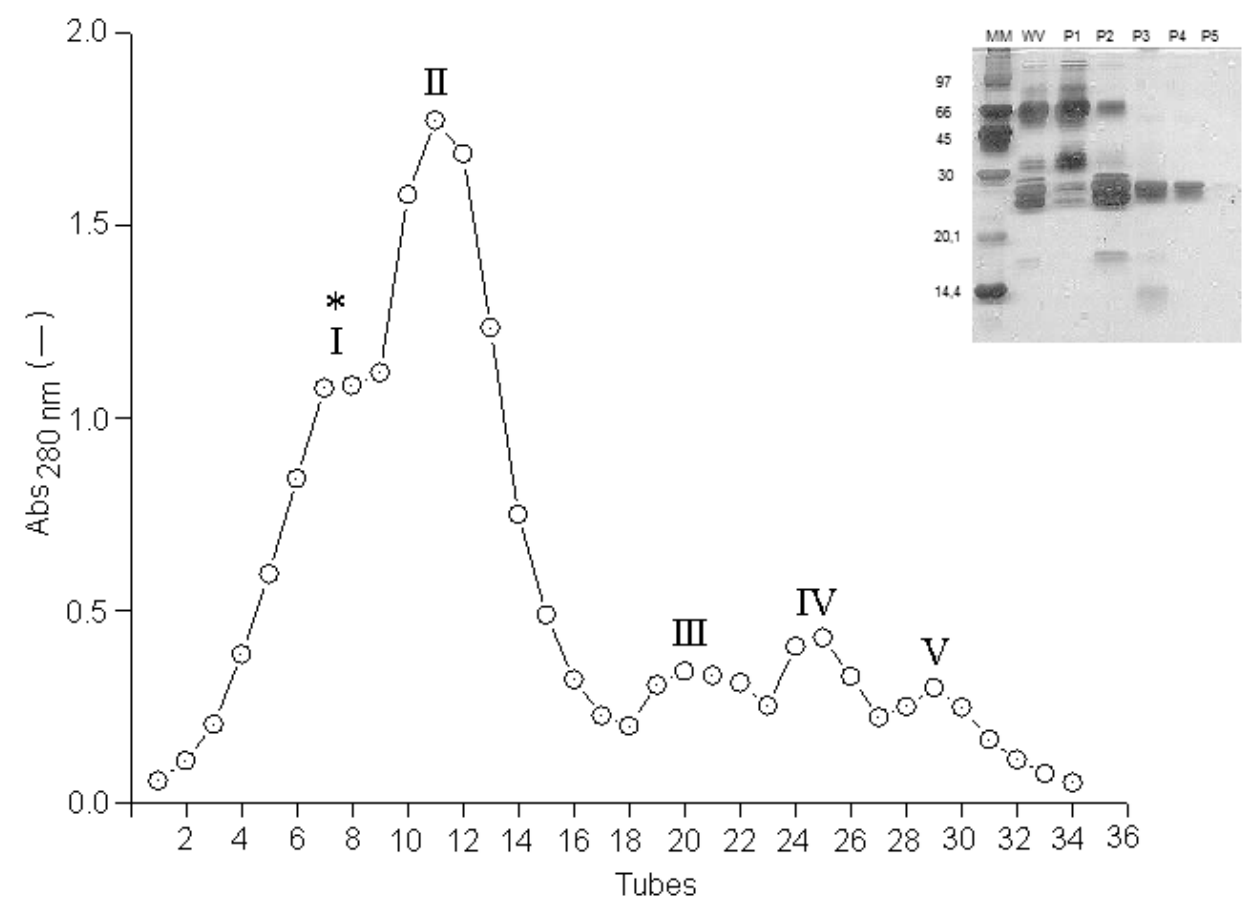

Fig. 2

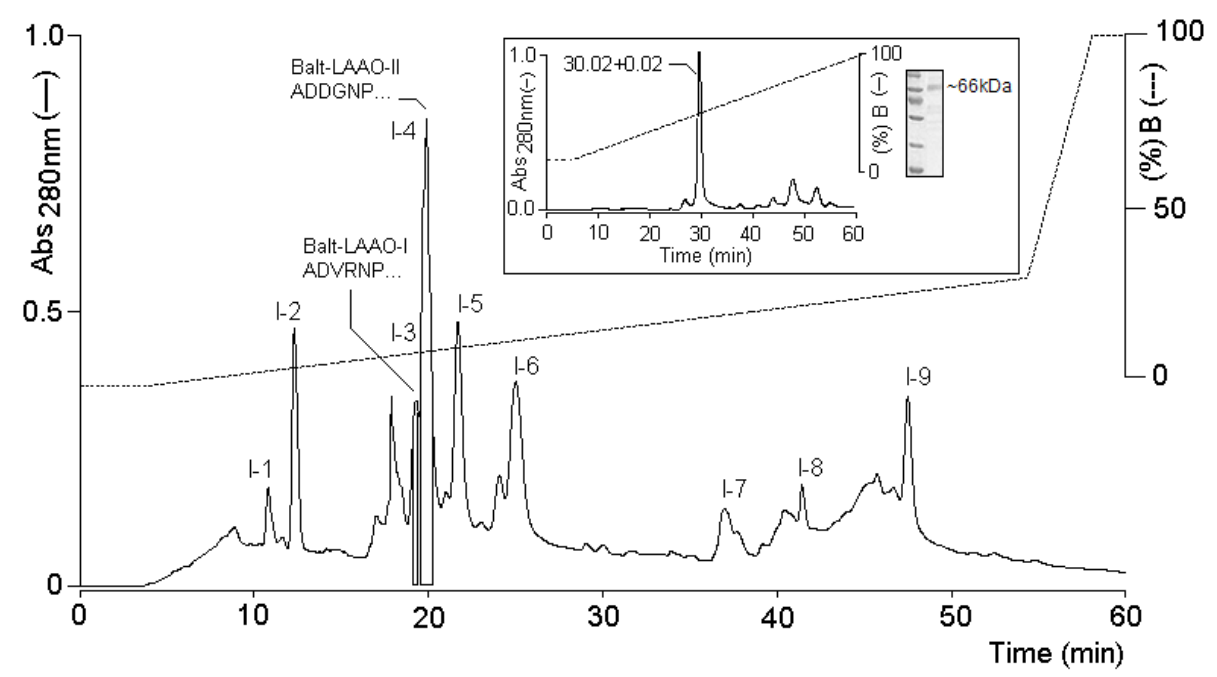

Fig. 3

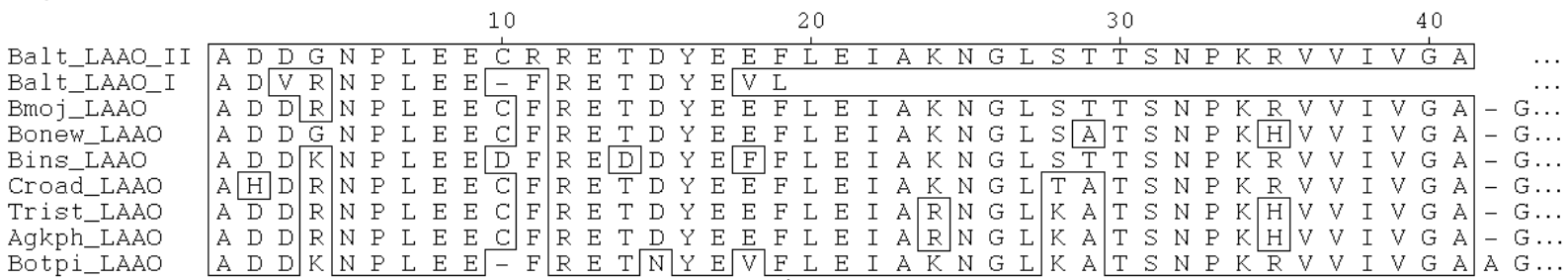


bioRxiv preprint doi: https://doi org/10.1101/2020.01.15.907758; this version posted January 16, 2020. The copyright holder for this preprint (which was not certified by peer review) is the author/funder. All rights reserved. No reuse allowed without permission.

Fig. 4
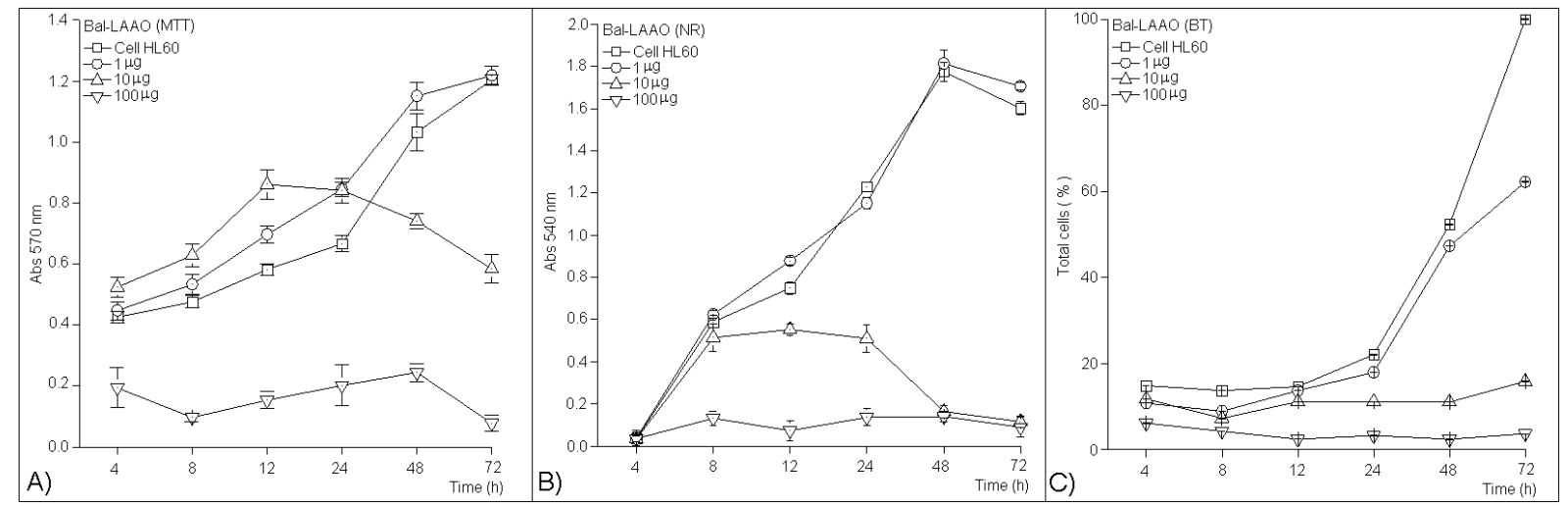

Fig. 5
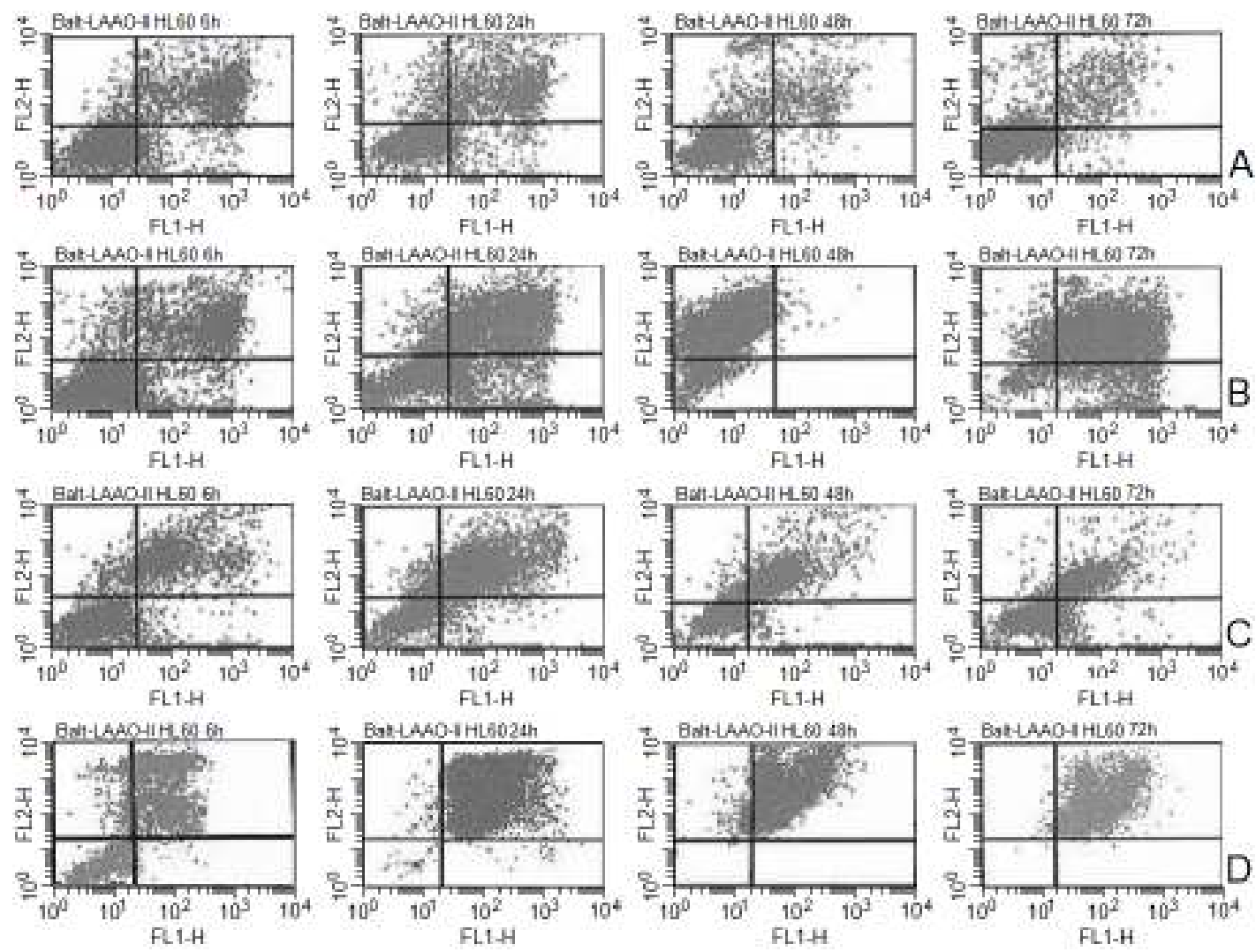
bioRxiv preprint doi: https://doi.org/10.1101/2020.01.15.907758; this version posted January 16, 2020. The copyright holder for this preprint (which was not certified by peer review) is the author/funder. All rights reserved. No reuse allowed without permission.

Fig. 6

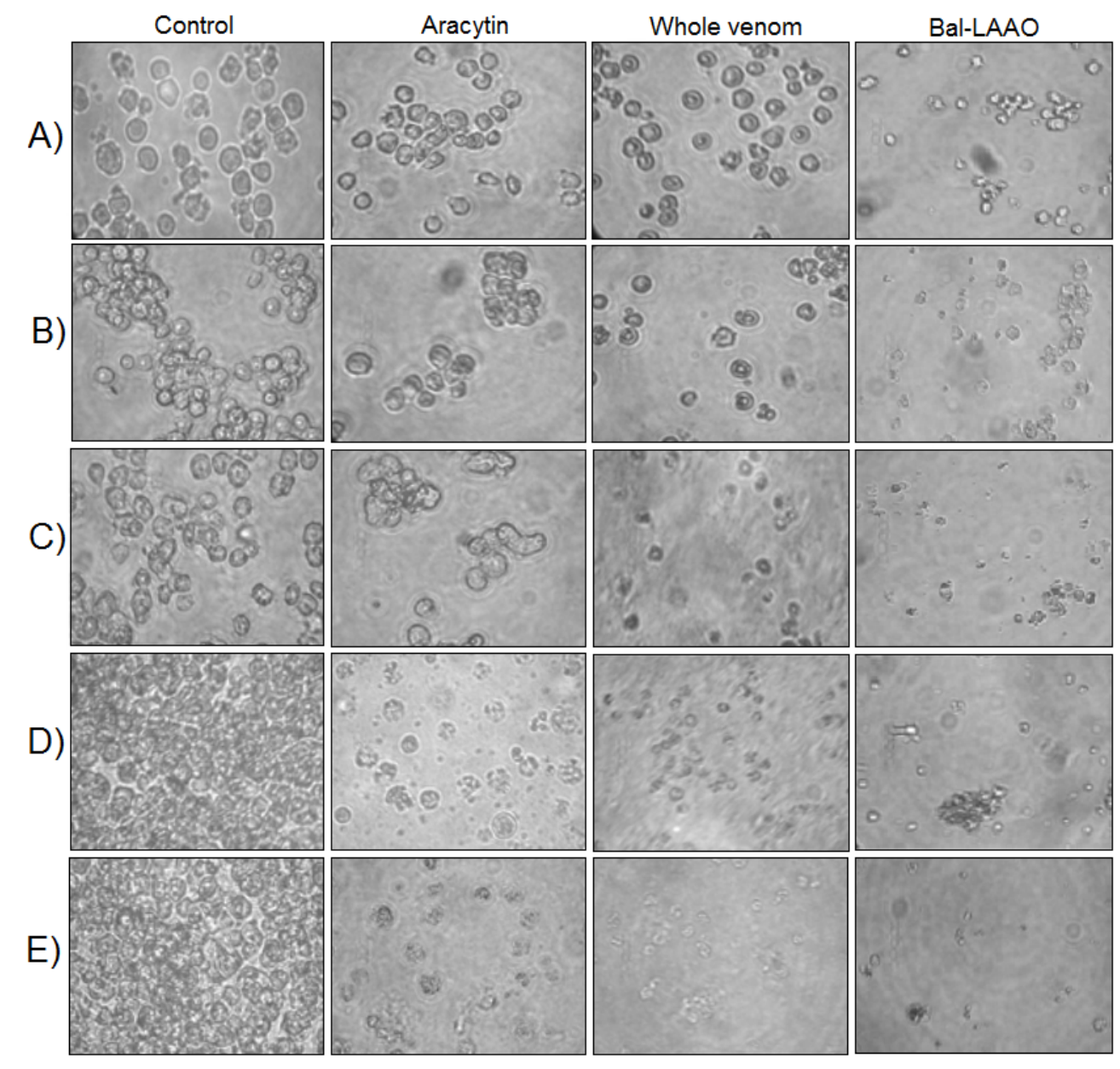

Fig. 7

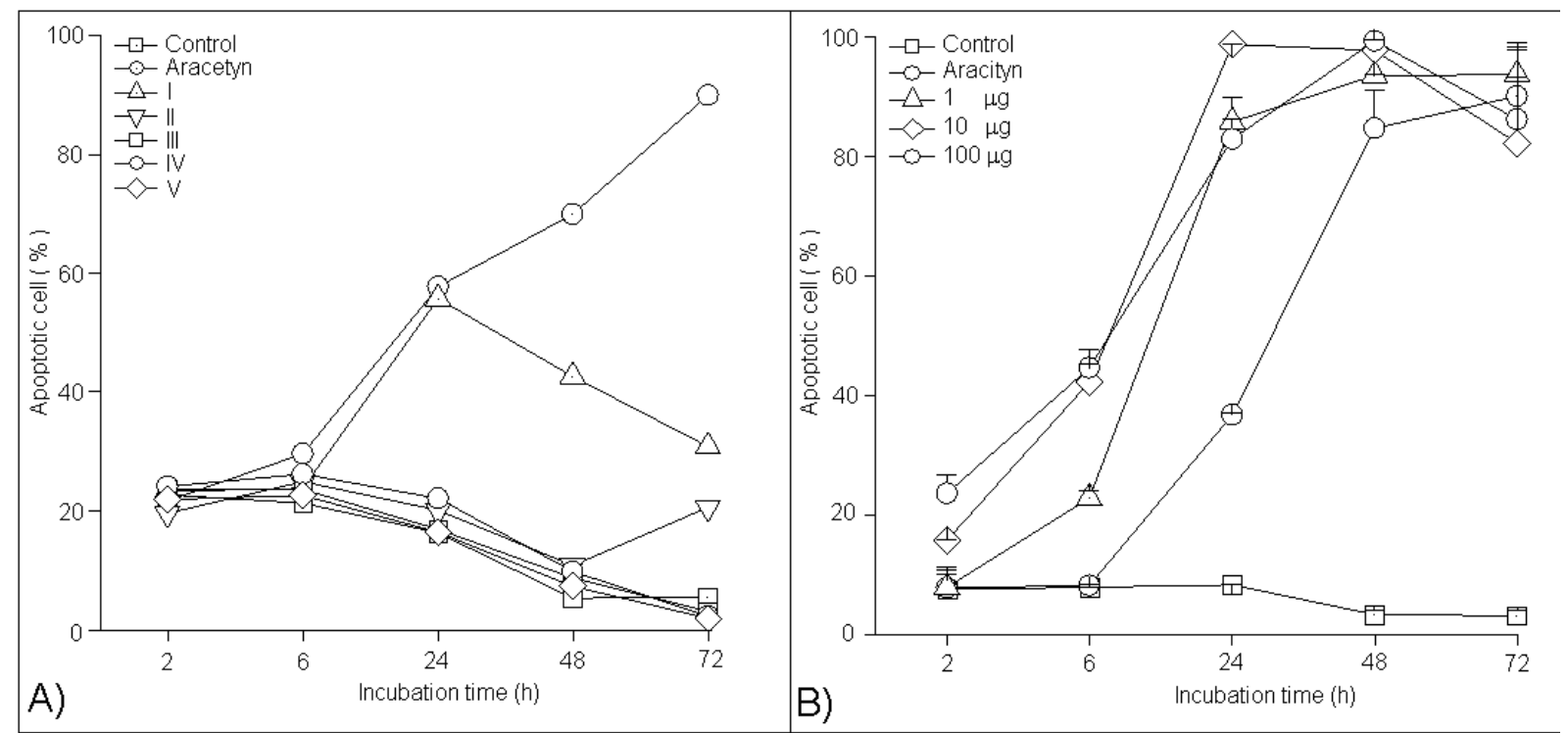


Table 1

\begin{tabular}{l|c|c|c|c|c|c}
\hline \multirow{2}{*}{ Activity } & \multicolumn{7}{c}{ Fractions } \\
\cline { 2 - 7 } & $I$ & $I I$ & $I I I$ & $I V$ & $V$ & $\begin{array}{c}\text { Balt- } \\
\text { LAAO-II }\end{array}$ \\
\hline Protein $(\mathrm{mg})$ & $\mathbf{6 4 . 1}$ & 47.4 & 11.4 & 8.4 & 3.2 & 0 \\
\hline Phosfolipase $\mathrm{A}_{2}\left(\mathrm{~A}_{420} \mathrm{~nm} / \mathrm{mg}\right)$ & 0.23 & 0.90 & $\mathbf{4 . 9 1}$ & 1.7 & 0 & 0 \\
\hline Esterase $\left(\mathrm{A}_{247} \mathrm{~nm} / \mathrm{mg}\right)$ & 5.6 & $\mathbf{1 0 . 9}$ & 0.42 & 0 & 0 & 0 \\
\hline LAO $\left(\mathrm{A}_{530} \mathrm{~nm} / \mathrm{mg}\right)$ & 3.0 & 0.52 & 0 & 0 & 0 & $\mathbf{6 . 8 9}$ \\
\hline Proteolitic $\left(\mathrm{A}_{280} \mathrm{~nm} / \mathrm{mg}\right)$ & $\mathbf{0 . 6 7}$ & 0.56 & 0.29 & 0 & 0 & 0 \\
\hline
\end{tabular}

